\title{
CONVERSATION ANALYSIS ON THE INTERVIEW TEST OF THE INDONESIAN SOLIDARITY PARTY'S LEGISLATIVE CANDIDATES
}

\author{
Farida Indri Wijayanti \\ Institut Agama Islam Negeri Surakarta \\ wijayanti.farida@yahoo.com
}

\begin{abstract}
Based on an analysis of 154 questions and their responses in the interview test of the Indonesian Solidarity Party's legislative candidates, this article gives a descriptive overview of interview stages and the types of question-response that are implemented in the conversation. Conversation Analysis (CA) is applied as an approach. Data are from video recordings of naturally occurring conversation in the interview test that are retrieved from https://www.youtube.com. Relying on the data, this paper shows a generic structure of the interview test (e.g. warm-up, confirmation, information exchange, and wrap-up), types of questions (e.g., wh-, disjunctive, declarative, tag, echo, narrative, and multiple), and types of responses (e.g., information, confirmation, marked confirmation, disconfirmation, choice of alternative answers, implication, code switched, and repetition). This paper reveals that wh-interrogative is used more commonly in the interview test than the other question types. Finally, information response in the form of clausal responses is mostly preferred by the legislative candidates.
\end{abstract}

Keywords: Conversation Analysis, interview stages, questions, responses

\begin{abstract}
Abstrak
Berdasarkan analisis terhadap 154 pertanyaan dan jawaban dalam tes wawancara terhadap bakal calon legislatif Partai Solidaritas Indonesia, artikel ini memberikan gambaran deskriptif tentang tahapan wawancara dan jenis pertanyaan-jawaban yang digunakan dalam percakapan. Artikel ini menggunakan pendekatan analisis percakapan. Data berasal dari rekaman video percakapan alami dalam tes wawancara yang diambil dari https://www.youtube.com. Berdasarkan data, makalah ini mendeskripsikan struktur generik tes wawancara (misalnya pemanasan, konfirmasi, pertukaran informasi, dan penyelesaian), jenis pertanyaan (misalnya penanda kata tanya, pilihan, deklaratif, tag, gema, narasi, dan multi), dan jenis jawaban (misalnya informasi, konfirmasi, konfirmasi bertanda, diskonfirmasi, pilihan jawaban alternatif, implikasi, alih kode, dan pengulangan). Artikel ini mengungkapkan bahwa kata tanya interogatif digunakan lebih banyak dalam tes wawancara dibandingkan jenis pertanyaan lainnya. Terakhir, jawaban informasi dalam bentuk klausa lebih banyak dipilih oleh bakal calon legislatif.
\end{abstract}

Kata kunci: Analisis Percakapan, tahapan wawancara, pertanyaan, jawaban

\section{INTRODUCTION}

Conversation Analysis (CA) based research has been used most frequently to analyze conversations in various settings such as debates, courtroom, police interrogations, language classroom, online chat, interviews, and others. However, there is only little research on interview 
test using CA approach. For many people, having an interview for the purpose of test or selection is quite tough. Interview test is usually not easy to be retrieved because it takes place in confidential settings. However, in today's public information openness era, public body is supposed to overtly publish interview tests. They should broadcast information in the media platform, so that it can be accessed by the public. Interview tests for legislative candidates of the Indonesian Solidarity Party, for example, are published in online media as a commitment of transparency and public relation strategy.

This paper aims to find language phenomena in the interaction between the interviewers and interviewees in the interview tests for the legislative candidates of the Indonesian Solidarity Party. This activity type belongs to a social domain which involves a constellation of three things, namely setting, topic, and participants (Archer, 2005; Rahardi, 2009). Questions and responses in the interview test of legislative candidates of the Indonesian Solidarity Party setting have a different value compared with the questions asked and responses given in other social domains. A panelist normally asks questions in a different way than a judge asks the defendant or a teacher asks questions to the students. Similarly, the way a legislative candidate gives a response is different from the way a defendant gives a response to questions asked by a judge or the way a student responses to the teacher's questions. Besides types of questions and responses, interview stages in interview tests are also interesting to be explored, because there is still little research on interview stages especially for the purpose of interview test.

A number of researchers have conducted studies on the types of questions and responses. Raymond (2015), for example, investigates questions and responses in Spanish monolingual and Spanish-English bilingual conversations. Bolden (2016) did a survey on affirming responses to polar questions in Russian conversation, while Lee (2016) examines disconfirming responses to polar questions. Some recent studies are conducted by Channon, et al. (2018), Karkkainen, et al. (2018), and Stivers et.al (2018). Channon, et al. (2018) investigated the problems of questions and responses in the LADO interview (Language Analysis for the determination of origin interviews), Karkkainen, et al. (2018) explored response packages including language and bodily resource, while Stivers et.al (2018) focused on children's responses to questions in peer interactions.

This study differs from the previous studies mentioned above as it focuses on the language phenomena which occurs in political domain. As stated by Clayman (2002, cited in Sidnell and Strivers, 2013, p. 655), the issue in interview and political communication remains unexplored and underdeveloped especially in the responses area and their construction. Therefore, this study discloses the interview stages, and the types of questions and responses in the interview tests of the legislative candidates of the Indonesian Solidarity Party.

\section{THEORETICAL REVIEW}

\section{Conversation Analysis}

Liddicoat (2007, p. 2) defines conversation analysis as an approach to the study of talk in interaction which grew out from the ethnomethodological tradition in Sociology developed by Harold $(1964,1967,1988)$. Ethnomethodology as a field of Sociology which studies the commonsense resources practices and procedures through which members of a society produce and recognize mutually intelligible objects, events, and courses of action. 
Hoey \& Kendrick $(2015$, p. 3 ) argue that in CA, talk is seen as a vehicle for action. Participants attend to talk not for its propositional content, nor as a simple medium of information transfer, but because they care about the actions getting done through talk (e.g. asking, requesting, complaining, noticing, and so on), and the real life consequences of those actions (see Schegloff, 1995). Hoey \& Kendrick (2015) further argue that talk is examined not as isolated utterances, but as talk-in-interaction, an activity that transpires in real settings between real people. In this respect, talks in interaction are always contextually situated, in the sense that they are produced by someone, for someone else, at a certain time, and in a certain way.

In a different note, Yule (1996, p. 77) states that in conversation analysis, the structure of conversation is referred to as adjacency pairs. An adjacency pair is defined as a unit of conversation that contains an exchange of turns by two speakers. Questions and answers are examples of adjacency pairs that are composed by two speakers that make a conversation.

\section{Interview Stages}

In many cases, an interview is based on question-answer sequences, where the interviewer asks questions and the informant provides answers (Have, 2004, p. 58). Before asking the next question, the interviewer often evaluates the relevance, details or adequacy of the answers in some manner. Harry (2017, p. 3) classifies four phases of interviews in which the interviewers examine the candidates' experience while referring to their resumes. The first five to ten minutes of a round of interview is used for becoming acquainted with the interviewee. Usually, this is the time for the behavioral interview, and no difficult technical questions are asked. The second phase is the technical interview when it is highly possible for a candidate to be asked to solve some coding interview problems. After the interviewers get the candidates' background information through the behavioral interviews, they move on to the technical interview. Technical questions require about 40 to 50 minutes if the overall interview time is an hour. Finally, the candidate is given time to ask a few questions.

Canavor \& Meirowitz (2010, cited in Jiang, 2013, p. 3), similarly, state that there are four generic structures in the interview, namely confirmation stage, warm-up stage, information exchange stage, and wrap-up stage. The warm-up stage, the information exchange stage, and the wrap-up stage are in compliance with the three obligatory moves in test interview. In the job interview conducted by Jiang (2013), there are also four steps which are found within the information exchange stage. They are concerned with the interviewer's inquiry in sequence about the interviewee's personal particulars, previous job, professional knowledge, and the expectations and obligations at the target position.

\section{Questions}

Hayano (2011, cited in Sidnel \& Stivers, 2013, pp. 396-412) defines a question as an utterance that craves a verbal or other semiotic response. Questions are used for social interaction, and they depend on factors such as how they are typed, who ask the questions, and the social and sequential context within which they are asked. For Stivers (2010), questions are sentence types that seek information from someone being treated as knowing someone who is unknowing. She states that a conversation reflects three primary question types: polar questions, question-word (q-word) questions, and alternative questions. Interrogative, tag and declarative questions make up the 
dominant sub-types of polar questions. In alternative questions, two full questions are conjoined by the word $o r$.

Englert (2010, p. 2676) classifies questions into three types, namely polar questions, content questions, and alternative questions. Polar questions are classified into polar interrogative / subject-verb inversion and declarative question / question that have no lexical, morphological or syntactic marking. Content questions start with a question word at the beginning with a clause which contains content questions, while in alternative questions the speaker expects the recipient to make a choice between two offered alternatives and to give a response by repeating one of the alternatives mentioned in the questions. Meanwhile, Barnbrook (1996, cited in Archer, 2005, p. 132) classifies some questions types as shown in Table 1 below. This classification is going to be used in the analysis of this paper.

Table 1. Classification of question types (Barnbrook, 1996)

\begin{tabular}{|c|c|}
\hline Question types & Definition \\
\hline wh-interrogative & $\begin{array}{l}\text { an interrogative structure that (usually) begins with a } \\
\text { wh-element }\end{array}$ \\
\hline negative wh- & a wh-interrogative that is negatively framed \\
\hline indirect wh-interrogative & $\begin{array}{l}\text { wh-interrogative whose interrogative element is } \\
\text { reported }\end{array}$ \\
\hline polar interrogative & $\begin{array}{l}\text { an interrogative structure that can be answered by } \\
\text { 'yes' or 'no' }\end{array}$ \\
\hline negatively framed polar & a polar interrogative that is negatively framed \\
\hline indirect polar & $\begin{array}{l}\text { a yes/no question whose interrogative element is } \\
\text { reported }\end{array}$ \\
\hline indirect negative polar & an indirect yes/no question that is negatively framed \\
\hline disjunctive interrogative & $\begin{array}{l}\text { a structure that asks } \mathrm{H} \text { to choose between two } \\
\text { expressed alternatives }\end{array}$ \\
\hline indirect disjunctive & $\begin{array}{l}\text { an alternative question whose interrogative element is } \\
\text { reported }\end{array}$ \\
\hline declarative question & $\begin{array}{l}\text { a structure that has the force but not the form of a } \\
\text { question }\end{array}$ \\
\hline tag question & $\begin{array}{l}\text { an elliptical interrogative structure attached to a } \\
\text { declarative }\end{array}$ \\
\hline echo question & $\begin{array}{l}\text { a structure that echoes something previously said by } \\
\text { another }\end{array}$ \\
\hline elliptical question & a question involving ellipsis \\
\hline rhetorical question & $\begin{array}{l}\text { an interrogative structure that does not seem to aspect } \\
\text { an answer (usually because the answer is self- } \\
\text { evident) }\end{array}$ \\
\hline question in narrative & questions that appear in speakers' narrative \\
\hline multiple interrogative & an utterance that contains more than one interrogative \\
\hline problematic & question type is ambiguous \\
\hline
\end{tabular}

\section{Responses}

Lee (2011, cited in Sidnell \& Stivers, 2013, pp. 415-429) states that in conversation analysis, responses are normally explicated by reference to some sequence initiating first action that makes them relevant. Responses to wh- questions (who, where, when, and so on) can be grouped into 
two types, namely (1) phrasal responses, which include grammatically lexical responses as well as phrasal ones and noun phrases, and (2) clausal responses, which refer to those with grammatically clausal units of talk that include a finite verb and the core and oblique arguments as well as clausal turns. As for responses to polar questions, they can be grouped into four types: (1) conforming responses (the questioner makes relevant to a choice between two alternative words by saying yes/no, yeah, or head shakes), (2) repetitional responses (partial or full repetition of the responses by confirming the inference of the respondent's previous talk), (3) marked confirmations (other forms of confirmation that are marked in the sense that they are alternatively lexical items but are not varieties of yes or no, such as absolutely or certainly), and (4) transformative responses (adjustment to alter the question's terms and agenda).

For Raymond (2015), response types for monolinguals are categorized as marked interjection, repetition, and interjection. Within the category of marked interjection, code switching is produced in responsive position in the speech of bilinguals. Stemstrom (1984, cited in Archer, 2005, p. 56) classifies various responses that can be seen in Table 2.

Table 2. Expected responses

\begin{tabular}{ll}
\hline Types of Question & Expected Response \\
\hline Request for information & Information \\
\hline Request for confirmation & Confirmation \\
\hline Suggestion & Affirmation \\
\hline Rhetorical, exclamatory & Comment \\
\hline Request for acknowledgement & Acknowledgement \\
\hline
\end{tabular}

Furthermore, Stivers at al. (2018, p. 28) give an overview of coding categories of response types as follows.

Table 3. Overview of coding categories of response type

\begin{tabular}{|c|c|}
\hline Answer & $\begin{array}{l}\text { Provides the information, confirmation or repair requested. } \\
\text { Something that indicates Yes/No; } M m \mathrm{hm} / \mathrm{Mm} \mathrm{mm} \text {; head } \\
\text { nods/shakes or statements of who, what, where, etc. }\end{array}$ \\
\hline Non-answer & $\begin{array}{l}\text { Talk or visible behavior that addresses the question but does } \\
\text { not provide the requested information, confirmation or repair }\end{array}$ \\
\hline Interjection & $\begin{array}{l}\text { Answers to polar questions such as yes/yeah/uh huh/mm hm or } \\
\text { no/neah/uh uh/mm mm or head nods/shakes. Marked } \\
\text { interjections include of course, certainly, absolutely }\end{array}$ \\
\hline Repetition & Repeating part or all of the answers \\
\hline Transformation & $\begin{array}{l}\text { Responding in a way that answers a somewhat different } \\
\text { question than was asked }\end{array}$ \\
\hline Valence & For polar question responses, answers that confirm the question \\
\hline Confirmation & was asked \\
\hline Disconfirmation & $\begin{array}{l}\text { Conversely to confirmation response, e.g. No, it didn't, or It } \\
\text { didn'tmake it }\end{array}$ \\
\hline
\end{tabular}

\section{RESEARCH METHOD}

The researcher applies qualitative methods. Bijeikiene \& Tamosiunaite (2013, p. 18) define qualitative methods as a set of methods that aims to gather an in-depth understanding of the 
phenomenon of the study. Qualitative research aims to answer the questions how and why, rather than what and how many. In this paper, the researcher is concerned with how questions and responses are investigated within the CA (Conversation Analysis) oriented methodology. CA research is done with how an analyst recorded, transcribed, and analyzed conversational data (Markee, 2000, p. 40).

\section{Data Source}

The data source in this research includes interview test documents of the legislative candidates of the Indonesian Solidarity Party that are retrieved from https://www.youtube.com. The data collection started by choosing samples of interviews based on simple random sampling. In simple random sampling, every person in a defined population has an equal chance to be chosen (Schleef and Meyerhoff, 2010, p. 7). The following table shows the data source.

Table 4. Panelists and legislative candidates involved in the interview

\begin{tabular}{lll}
\hline Panelists & Legislative Candidates \\
\hline 1) Mari Elka Pangestu & 1) Giring Ganesha, (08 November 2017) \\
2) Hamdi Muluk & https://www.youtube.com/watch?v=VVau05ecIuI \\
3) Suci Mayangsari & 2) Surya Tjandra, (08 November 2017) \\
4) Prof. Dr. Mohammad Mahfud MD & https://www.youtube.com/watch?v=atDQCBNRBcI \\
5) Grace Natalie & 3) Adrian Fernando, (09 November 2017) \\
6) Dr. Zainal Arifin Mochtar, SH, LL.M & https://www.youtube.com/watch?v=Ab9xSwTD_Hg \\
7) Bibit Samad Riyanto & 4) Dr. drg. Amelia Sari, (09 November 2017) \\
& https://www.youtube.com/watch?v=VQF8aAw2ivs \\
& 5) Dadang Setiawan, (09 November 2017) \\
& https://www.youtube.com/watch?v=-YX1v716XVw \\
& 6) Danik Eka R, (09 November 2017) \\
& https://www.youtube.com/watch?v=MPeTqr-ygxY \\
& 7) Andy Budiman, (09 November 2017) \\
& https://www.youtube.com/watch?v=47P4_rdJN1Y \\
\hline
\end{tabular}

\section{Data Transcription}

The data are presented into a word-by-word transcription in order to know the interview stages and speeches that contain the questions and responses that the panelists and legislatives candidates used in their talk. Only a very limited suprasegmental elements is used in the transcription. Therefore, the transcriptions do not show vocalization such as laughter, length of silences, inhalations or exhalations, faster and slower speech or other multimodal transcriptions.

\section{Data Analysis}

The technique for analysing the data began with an observation of the data in order to see the interview stages. After that, based on the patterns of the questions and responses found in the data, the questions and answers were classified into categories or types. Finally, the questions and responses types are calculated using percentage in order to find the frequency of the occurrences. 


\section{FINDINGS AND DISCUSSION}

\section{Interview Stages}

The first structure in the interview test of the legislative candidates of the Indonesian Solidarity Party is warm up stage. Unlike job interviews, the interview test proceeded with a material presentation for approximately seven minutes. In the presentation, the legislative candidates did not only describe their personal identity and background, but they also elaborated their program, vision, and mission. In the warm up stage, no difficult technical questions were asked to the legislative candidates, as demonstrated in examples (1) and (2).

(1) Grace:

Dadang:

Grace:

Dadang:

Grace:

Dadang:

Adrian:

\section{Apa kabar?}

How are you?

Baik.

Fine

Pak Dadang dateng waktu acara di acara DPR?

$M r$. Dadang, did you come to the House of Representative's event?

Iya datang.

Yes, I did.

Ok. Silahkan pak Dadang ini waktunya 7 menit. Tolong ini nanti Tasya akan memberikan peringatan aba-aba kalo tinggal 3 menit waktu mau habis. 7 menit waktu singkat pak, jadi harus diukur supaya yang pentingpenting nanti nyampe.

Ok. Please, Mr. Dadang. The time is 7 minutes. Tasya will give you a sign when time is only 3 minutes left. 7 minutes is a short time, sir, so you have to manage the time so that important things can be delivered.

Selamat siang. Assalamualaikum warohmatullahi wabarokatuh. Salam sejahtera bagi kita semua. Saya Dadang Setiawan akan sedikit memberikan ee gambaran tentang visi misi khususnya kaitan dengan nanti untuk legislatif Partai Solidaritas Indonesia...

Good afternoon. May the peace, mercy, and blessings of Allah be upon you. Peace be upon all of us. I'm Dadang Setiawan; I will give a short overview of the vision and mission, especially with regard to the legislative of the Indonesian Solidarity Party later...

(2) Prof. Mahfud: Sedikit saja, saya tanya sebenarnya yang didiskusikan saudara menarik. Saya ingin saudara, saya saya tidak persoalkan saudara beragama apa tapi saya ingin tahu anda beragama apa?

Just a little, actually what you have discussed is interesting, I want you.. it doesn't matter what your religion is, but I want to know what is your religion?

\section{Saya Kristen pak.}

I'm a Christian, sir.

As can be seen in example (1), in the warm up stage the panelist firstly greeted the legislative candidate and informed him about the guidelines of the interview. The legislative candidate started his presentation by greeting the panelists. The presentation ended with a closing statement (regarding and thanking expression). In example (2), after presenting his material, the legislative candidate was asked by the panelist about his personal identity (his religion). The response was quite brief without any elaboration. 
In some cases, the warm up stage is only presentation stage by the legislative candidate and it is combined with confirmation stage. In this stage, technical questions are formulated in order to get some responses in the form of confirmation and argumentation as illustrated in example (3).

(3) Giring: Selamat pagi buat dewan juri terhormat, Ibu Mari, Pak Hamdi. ...Wassalamualaikum warrahmatullahi wabarokatuh. Saya adalah seorang negarawan yang siap melayani masyarakat Indonesia, Terima kasih.

Good morning to the honorable jury Mrs. Mari, Mr. Hamdi. ... May the peace, mercy, and blessings of Allah be upon you. I am a statesman who is ready to serve the Indonesian society. Thank you.

Hamdi: $\quad Y a$, Giring, basic propose Anda yang paling penting itu karakter?

Yes, Giring, your basic important proposal is character?

Giring: Pendidikan karakter.

Character education

Hamdi: $\quad$ Karakter itu kan?

That is character, isn't?

Giring: $\quad$ Iya.

Yes.

Hamdi: $\quad$ Itu kan starting poin anda dari situ, tapi saya... Anda sudah pahamin betul tidak inti tentang ujian bakat itu sebelum Anda usulkan?

That's your starting point, but I... Have you really understood or not about the core of the talent test before you proposed?

Giring: Karena beberapa bulan yang lalu kan Kemendikbud kita yang baru mengajukan hal yang sama kan ke Pak Jokowi, tapi pak Jokowi bilang ga lah tetap aja ada ujian nasional. Sebetulnya ujian nasional itu kalo menurut saya seh untuk pelevelan agar nanti mereka bisa masuk ke universitas kan.

Because a few months ago our new Ministry of Education and Culture who just proposed the same thing to Mr. Jokowi, but he said that there wasn't any national examination. Actually, in my opinion, the national examination is for the leveling so that later they can enter the university, is that right?

In the confirmation stage, questions are made into more difficult formulation in order to get responses that are supported by identification and evidence about the program, vision and mission. As in example (3), the question about the candidate's program (character education) was asked and confirmed by panelist. Confirmation and argumentation response related to the proposed program is expected.

Another stage in the interview test of the legislative candidates is information exchange stage. In some cases, confirmation stage and information exchange stage are alternately shown during the conversation. The characteristic of information exchange stage is any information exchange between participants in the conversation. Unlike confirmation stage that only contains questions and responses, in the information stage the question and answer contain information exchange between the panelists and legislative candidates as shown in example (4) below.

(4) Prof. Mahfud: Ok. Ini tadi Ibu untuk pemberantasan korupsi itu mengusulkan perluasan definisi korupsi, ya dok? 
Ok. You said for the eradication of corruption you proposed to extend the definition of corruption, didn't you?

Dr. Amelia: $\quad$ He em.

$\mathrm{Hm}$.

Prof. Mahfud: Apa yang diperluas?

What is extended?

Dr. Amelia: Jadi tidak hanya uang korupsi itu, jadi korupsi itu bisa waktu, bisa lingkungan, sepertinya contohnya kayak gini ini sudah ada jelas-jelas ada tulisan dilarang merokok, tapi dia merokok juga. Sementara ada orang-orang di situ. Itu kan korupsi lingkungan di mana orang lain ter... terganggu kesehatannya gara-gara dia merokok, itu korupsi.

So, corruption is not only money, but it can also be time, it can be environment. It seems like, for example like this, it's already clearly written 'no smoking', but he smokes too. While there are people there. That's environmental corruption because it's harmful for other people's health because he smokes. That's corruption.

Prof. Mahfud: Itu mau dijadikan masuk tentang korupsi, iya?

That would be included in corruption, wouldn't it?

Dr. Amelia: $\quad G a$, itu lebih ke budaya, jadi orang itu sadar bahwa kayak gitu tu korupsi loh.

No, it's more about culture, so the person realized that it was corruption.

Prof. Mahfud: $\quad$ Secara sosiologis itu ya memang memang definisinya korupsi kegiatan menyimpang itu korupsi. Cuma kalo definisi korupsi menurut hukum ya cuma tiga, merugikan negara, melanggar hukum, memperkaya diri sendiri, sedangkan di luar itu bukan korupsi dalam arti hukum.

Sociologically, that is indeed the definition of corruption. Deviant activity is corruption. However, there are only three definitions of corruption according to the law: you disadvantage the state, you violate the law, and you enrich yourself, while outside of those three definitions it is not corruption in the legal sense.

Dr. Amelia: Iya.

Yes.

Example (4) shows an exchange of information between the panelist and the legislative candidate about the definition of corruption. The questions were asked in the form of wh-question to request some information about the definition of corruption. The legislative candidate viewed that corruption could be in the form of time, money, and environment. The next question was to confirm the response that was already made by the legislative candidate. In this stage, the panelist further elaborated the definition of corruption. The panelist stated that corruption mentioned by legislative candidate was sociologically called as social corruption, but corruption according to law covered three aspects, namely detrimental effect on the state, violation of the law, and selfenrichment. In the information exchange, the information was not only designed by the legislative candidate, but it was also elaborated by the panelist. 
The last structure in the interview test is the wrap-up stage. The wrap-up stage is approximately about two to five minutes before the interview ends. This is meant to give a chance to the third panelist to ask questions. Observe examples (5) and (6) below.

(5) Grace: Mungkin ini yang terakhir dan singkat, ada yang cerita soal orang yang baik di DPR kan ee bisa aja bilang gampang bisa berubah, orang-orang yang dulunya kritis mampu berubah. Ada lagi orang-orang yang tetap berusaha ee benar di DPR mendapat ancaman-ancaman. Kemarin ada yang cerita mobilnya ee dibaret-baret, dan sebagainya. Dokter kemudian sebagaimana sebagai seorang perempuan, dan juga profesi sebelumnya ndak ngalamin seperti itu nanti kalo ada tantangan seperti itu di DPR bagimana?

Maybe this is the last and very short, there is a story about good people in the house of representatives who said it's easy to change. People who used to be critical can change. There are also people who keep trying to be right in the house of representatives but they are threatened. Yesterday someone said that his car was scratched and so on. Doctor, as a woman, and in your previous profession, didn't you experience like that? How if there will be challenges like that in the house of representatives?

(6) Grace: Oke, ya, waktunya habis, terima kasih Pak Dadang.

Okay, yes, time's up, thank you, Mr. Dadang.

Dadang: Baik, terima kasih.

Okay, thank you.

In the wrap-up stage as demonstrated in example (5), there are expressions that indicate a closing session: 'Maybe this is the last (question) and (it will be) very short'. The wrap-up stage in example (6) is identified by a closing statement 'time is up' and 'thank you'.

\section{Types of Questions}

There are seven types of questions found in the data. The question and answer session for the interview test took about fifteen minutes which contains approximately 15 to 30 questions for each video. The seven types are as follows.

\section{a. Wh-interrogative}

The wh-interrogative structure in the interview test is indicated by the use of wh- elements or whinterrogatives which include what, how, why, how many, how far, where, and which. Examples of the wh-interrogatives are given in example (7) to (9).

(7) Maria: $\quad$... Kenapa kalo Anda punya passion begitu besar untuk perubahan kenapa tidak memilih partai lain yang akan lebih mungkin mempunyai suara yang lebih besar di DPR?

...If you have such a big passion for a change, why don't you choose another party that will be more likely to have a bigger voice in the house of representatives? 
(8) Maria: Dan kira-kira perjuangan atau program apa yang Anda ingin goalkan di DPR baik Undang-Undang ataupun program apa yang Anda rasa Anda bisa mempunyai Anda akan perjuangkan?

And approximately what kind of effort or program do you want to aim for in the house of representatives, either in the laws or in what programs do you feel you can fight for?

(9) Mochtar: Ok, jelas, jelas Anda kan banyak kepentingan di sana, Anda punya kepentingan pribadi, ada kepentingan partai, ada kepentingan partai lain, bagaimana anda meramu sebuah perbedaan?

Okay. It's clear that you have a lot of interests there, you have personal interests and you have party interests. There are interests of other parties. How do you gather differences?

The above examples show that the panelists design the wh-interrogatives in order to get information about why (the reason for not choosing another party) as in example (7), what (some programs) as in example (8), and how (condition or manner in gathering differences) as in example (9).

\section{b. Disjunctive interrogative}

The panelists design disjunctive interrogatives by asking the legislative candidates to choose between two or more alternatives. As demonstrated in example (10), the question shows two possible alternatives between threatened or suffering, and it requires the legislative candidate to choose one of them.

(10) Prof. Mahfud: Terus soal intoleransi, apa benar sekarang Indonesia ini sedang terancam atau sedang mengidap penyakit intoleransi?

Then the problem of intolerance, is it true that Indonesia is being threatened or is it suffering from intolerance?

Dr. Amelia: Mengidap

Suffering.

\section{c. Declarative question}

Declarative questions are expressed in the form of a declarative sentence, but it is spoken with a rising intonation at the end of the utterance, as seen in example (11) below.

(11) Hamdi: Anda melihat bahwa ke depan tidak ada standar?

You see that in the future there are no standards?

Giring: Bukan tidak ada standar, bahwa kalo ketika ada standarisasi boleh ketika dia mau ke level universitas. Itu universitas yang ngeset standar masing-masing. UI ngeset standar, UGM ngeset standar.

No, it doesn't mean there is no standard, standardization is allowed for university level. Universities will set their own standards. UI sets its standard, UGM sets its standard. 
This type of question is used by the panelist in order to ask for verification or confirmation response. Example (11) demonstrates that the panelist wanted to confirm about the previous statement made by the legislative candidate that in the future there would be no standards for national examination.

\section{d. Tag question}

Tag questions in the interview test are used to ask for agreement or confirmation, and it can also indicate an emphasis. A tag question is formulated in a declarative statement but then it is turned into a question by the addition of an interrogative or mini question, as seen in example (12). In this case the tag question $y a$ 'yes' is used.

(12) Suci: Saya mau tanya, dulu kan banyak bergulat di buruh, ya?

I want to ask, you used to struggle a lot for the laborers, didn't you?

Surya: Iya.

Yes.

\section{e. Echo question}

The characteristic of an echo question is a repetition or echo of something that has been previously mentioned, as illustrated in example (13). In this case the word kampanye 'campaign' was repeated by the panelist in order to get a clearer description.

(13) Grace: Ok. Sudah ada rencana bapak gimana mensosialisasikan diri supaya orang milih bapak nanti?

Okay. Are there plans for you how to socialize yourself so people will choose you later?

Dadang: Kampanye.

Campaign.

Grace: Iya kampanye seperti apa?

Yes, what kind of campaign?

\section{f. Question in narrative}

Questions may also appear in a speaker's narrative. A narrative contains an account of series of related events, experiences, or the like. In example (14), the panelist shared her knowledge or experience of related events about the threats and challenges as a legislative before she asked a question. Observe example (14) below.

(14) Grace: Mungkin ini yang terakhir dan singkat, ada yang cerita soal orang yang baik di DPR kan bisa aja bilang gampang bisa berubah, orang-orang yang dulunya kritis mampu berubah. Ada lagi orang-orang yang tetap berusaha benar di DPR mendapat ancaman-ancaman. Kemarin ada yang cerita mobilnya ee dibaretbaret, dan sebagainya. Dokter kemudian sebagai seorang perempuan, dan juga profesi sebelumnya ndak ngalamin seperti itu, nanti kalo ada tantangan seperti itu di DPR bagimana?

Maybe, this is the last and very short, there is a story about good people in the house of representatives who say it is easy to change. People who used to be 
critical can change. There are also people who keep trying to be firm in the house of representatives but they are threatened. Yesterday there was a story about a car being scratched, and so on. Doctor, as a woman, and also in your previous profession, didn't you experience like that? How if there are challenges like that in the house of representatives?

Example (14) shows that the panelist formulated a question nanti kalo ada tantangan seperti itu di DPR bagaimana? 'how if there are challenges like that in the house of representatives?' after a narrative.

\section{g. Multiple interrogative}

In some cases, a question may contain more than one interrogative, as shown in example (15) below.

(15) Hamdi: Saya membayangkan perdebatan di DPR pastinya akan seru banget itu. Bagaimana nanti kan Anda meyakinkan sekian banyak orang bahwa ini dasarnya afirmasi untuk kaum muda itu kan. Iya ga?

I imagine the debate in the house of representatives will definitely be very exciting. How would you convince so many people that this is basically an affirmation for young people. Isn't that right?

Surya: $\quad$ Iya, minimal debat itu aja udah sebuah kemajuan pak.

Yes, at least the debate is already a progress, sir.

To sum up, most of the questions asked in the interview tests belong to the whinterrogatives which contributes $48.05 \%$ of the total question types. It seems that the panelists preferred the wh-interrogatives as they expected to get informative responses in the form of explanation and argumentation. The next preferred type of question is polar questions. The use of declarative and tag questions frequently occurred because the panelists would like to get some clarification or verification about related issues. Other types of interrogatives such as disjunctive, echo, narrative, and multiple questions are rarely formulated. They are used in some cases which are relevant with the context. Table 5 demonstrates the distribution of the types of questions that occur in the data.

Table 5. Distribution of Question Types

\begin{tabular}{lcc}
\hline Types of Questions & Total & Frequency \\
\hline Wh- interrogative & 74 & $48.05 \%$ \\
\hline Disjunctive interrogative & 3 & $1.95 \%$ \\
\hline Declarative question & 30 & $19.48 \%$ \\
\hline Tag question & 37 & $24.03 \%$ \\
\hline Echo question & 3 & $1.95 \%$ \\
\hline Question in narrative & 3 & $1.95 \%$ \\
\hline Multiple question & 4 & $2.60 \%$ \\
\hline Total & $\mathbf{1 5 4}$ & $\mathbf{1 0 0 \%}$ \\
\hline
\end{tabular}


As for the question words, the question word 'what' is dominantly used. The distribution of the wh-interrogatives can be seen in table 6 below.

Table 6. Distribution of Wh-Interrogatives

\begin{tabular}{ccc}
\hline $\begin{array}{c}\text { Wh-interrogative } \\
\text { Types }\end{array}$ & Total & Frequency \\
\hline Why & 5 & $6.76 \%$ \\
\hline How & 24 & $32.43 \%$ \\
\hline What & 35 & $47.30 \%$ \\
\hline How many & 4 & $5.41 \%$ \\
\hline Where & 3 & $4.05 \%$ \\
\hline How far & 1 & $1.35 \%$ \\
\hline Which & 2 & $2.70 \%$ \\
\hline Total & $\mathbf{7 4}$ & $\mathbf{1 0 0 \%}$
\end{tabular}

The use of 'what' indicates that most wh-interrogatives are formulated to get some information about things and actions. In the interview test of legislative candidates, 'what' are most frequently used to ask identification of related political problems such as visions, missions, plans, ideas, etc. In addition, 'how' are used to describe the manner that identification responses are done. Other question words are rarely used by panellist. They only support some questions that have not been clearly identified with the use question words 'what' and 'how'.

\section{Types of Responses}

The types of responses found in the interview tests of legislative candidates are as follows.

\section{a. Information response}

The legislative candidates provide requested information explicitly, as seen in examples (16) and (17) below.

(16) Bibit: Itu masuk ranah mana?

What domain is it?

Andi: $\quad$ Kejahatan pak.

Crime, sir.

(17) Grace: Danik mungkin bisa dijelaskan kenapa Danik milihnya ini yang diperjuangkan?

Danik, can you explain why you choose this and want to fight for this?

Danik: $\quad$ Sebelum berbicara dapil, kebetulan saya ini memang lahir di lingkungan perkebunan pertanian dan di Jember banyak sekali sengketa terkait dengan hak guna usaha. Biasanya ini kan terjadi di daerah-daerah perkebunan dan lain sebagainya. Warga sering menunjukkan mereka punya sertifikat, bukan sertifikat tapi istilahnya punya surat keterangan tanah dari kecamatan. Tapi ternyata jika bersinggungan langsung dengan misalnya korporasi dan sebagainya ini seringkali dikalahkan...

Before talking about the electoral district, it happens that I was born in an agricultural plantation environment, and in Jember there are many disputes 
which are related to the cultivation right on land. Usually this happens in plantation areas, and so on. Residents often show they have certificates, not a certificate, but the term is a land note from the district. However, it turns out that if it is in direct contact with, for example, corporations and so on, this is often defeated...

Example (16) shows that the information is explicitly answered by the legislative candidate in the form of a brief phrasal response. However, in example (17), we can see a longer phrasal response which provides some analytical information.

\section{b. Confirmation response}

In this type of response, The legislative candidate established that what had been proposed by the panelist was true. This can be seen in example (18). The response 'yes' indicated that the legislative candidate wanted to strengthen the statement.

(18) Grace: Oke, tadi saya lihat bapak ee programnya terakhir memperkuat UndangUndang ITE?

Okay, just now I saw that your last program is to strengthen the Electronic Transaction Information?

Dadang: Iya.

Yes.

\section{c. Marked confirmation response}

The legislative candidates may make another form of confirmation that is marked in the sense that it is not in the form of yes or no. In example (19), the marked confirmation response betul 'right' was preferred by the legislative candidate.

(19) Prof Mahfud: ... terakhir saudara tadi punya mutu mengkritisi, muda dan kritis, betul ya?

... last time you (said) you have the quality of criticizing, (you're) young and critical, is that right?

Adrian: $\quad$ Betul.

That's right.

\section{d. Disconfirmation response}

A disconfirmation response is characterized by an utterance which establishes something that has been proposed is false. This can be seen as in example (20).

(20) Hamdi: Saya tanya satu hal lagi, waktu Anda tidak lolos di KPK di DPR, Anda kecewa?

I ask one more thing, when you did not qualify for the corruption eradication commission in the house of representatives, were you disappointed?

Surya: Nggak pak, memang politik kan selera pak. Saya tahu saya cukup nilainya. No, sir. Actually politics is interest, sir. I know my score is enough. 
In example (20), the panelist asked the legislative candidate whether he was disappointed when he did not qualify for house of representatives. Disconfirmation response is shown by the use of ' $n o$ ' to indicate a disagreement with the panelist's statement.

\section{e. Implication response}

In implication response, the legislative candidate did not provide an explicit 'yes' or 'no' statement. Rather, he made an inference as can be seen in example (21).

(21) Hamdi: Ide itu Anda setuju sebenarnya?

Did you really agree with the idea?

Giring: $\quad$ Karena saya mencoba untuk saya ambil saya suka banget baca lihat bahwa negara-negara yang hebat harus memiliki mental yang hebat, dan itu membutuhkan revolusi.

Because I tried to take it, I like to read that great countries must have great mentality, and that requires revolution.

\section{f. Choice of alternative answers}

Choice of alternative answers was made by the legislative candidates when they were asked to choose between two or more expressed alternatives, as illustrated in example (22).

(22) Bibit: ...Nah menurut Anda korupsi itu kebiasaan, mismanajemen atau kejahatan? ...Well, do you think corruption is a habit, mismanagement, or crime?

Andy: Menurut saya adalah mismanajemen...

In my opinion, it is mismanagement.

\section{g. Code switched response}

A code switched response indicates a shift from Indonesian to English or vice versa. In example (23), the legislative candidate used the English words 'fake news'.

(23) Grace: Apa itu maksudnya yang mau diperkuat yang mana dan sebagainya?

What do you mean, which one do you want to strengthen?

Dadang: Khususnya fake news. Fake news itu sering itu yang membuat apa intoleransi sering muncul.

Especially fake news. Fake news often times makes intolerance frequently appear.

\section{h. Repetitional response}

Repetitional response is characterized by the use of partial or full repetition of the responses by confirming the inference of the previous talk, as illustrated in example (24). The word 'firm' was repeated four times in the response by the legislative candidate in order to emphasize a significant idea.

(24) dr. Amelia: Saya sendiri sebagai perempuan saya rasa saya cukup tough dan firm. Saya firm orangnya. Jadi, saya kira kalo saya punya prinsip tidak segampang itu dilanggar. Jadi kalo saya artinya gara-gara sekeliling saya 
harus ikut. Saya rasa saya tetap bisa firm. Kalo saya ga bisa firm saya rasa saya ga akan berani mengajukan diri saya sebagai anggota politik dan bilang ingin perubahan.

I myself as a woman think I am quite tough and firm. I'm a firm person. So, I think it's not easy for me to violate the principle. Therefore, I don't have to follow my surroundings. I think I can still be firm. If I can't be firm, I don't think I would dare to put myself up as a politician and say I want a change.

To sum up, Table (7) demonstrates that the most dominant response in the interview test is information, which contributes $51.30 \%$ of the total response types. Information responses indicate the strategy of the legislative candidates in presenting their knowledge, idea, comprehension, analysis, and application to the related questions. By giving information, the legislative candidates intend to address the panelists' questions either explicitly or implicitly. Information is needed to answer questions that cannot be answered by simply yes or no. This type of response is in line with most frequently questions asked by the panellists which are categorized as requests for information. Information responses are followed by confirmation responses (28.57\%), and then disconfirmation $(9.09 \%)$. This indicates that something proposed by the panelists is true, so that the responses given support the statement uttered by the panelists. Other types of responses are marked confirmation, implication, alternative answer, code switched, and repetition (less than $5 \%$ of the total occurrence).

Table. 7 Distribution of Response Types

\begin{tabular}{lcc}
\hline Response Types & Total & Frequency \\
\hline Information & 79 & $51.30 \%$ \\
\hline Confirmation & 44 & $28.57 \%$ \\
\hline Marked Confirmation & 5 & $3.79 \%$ \\
\hline Disconfirmation & 12 & $9.09 \%$ \\
\hline Implication & 6 & $4.55 \%$ \\
\hline Choice of alternative answers & 3 & $2.27 \%$ \\
\hline Code Switched & 3 & $2.27 \%$ \\
\hline Repetitional & 2 & $1.52 \%$ \\
\hline Total & $\mathbf{1 5 4}$ & $\mathbf{1 0 0 \%}$ \\
\hline
\end{tabular}

\section{CONCLUSION}

This article has documented a range of ways in which the speakers in the interview test of the Indonesian Solidarity Party's legislative candidates design their questions and responses in the interview conversation. The conversation shows a generic structure that begins with a presentation of the legislative candidates in the warm up stage, followed by technical questions and identifying responses in the confirmation and information exchange stage. Finally, questions by the third panelist is a signal of the wrap-up stage which indicates the end of the conversation in the interview test.

The findings show that the questions and answers formulated in the interview tests are very different from those in mundane conversation. The interactional setting in the interview test 
of legislative candidates is more formally structured in the panel format, where the type and order of turns are determined by the panelists as chairs. The panelists have the roles and rights in giving questions directly. The legislative candidates establish responses to address the panelists' questions, and they are not allowed to make a request to the panelists. This paper presented a distinctive system of questions and responses that occurred in a political domain. It is hoped that further work in different social domains can be done in order to extend a different system of questions and responses.

\section{Note}

The author would like to thank two anonymous reviewers for their very helpful comments on the earlier draft of the paper.

\section{REFERENCES}

Archer, D. (2005). Questions and answers in the English courtroom (1640-1760): A sociopragmatic analysis (Vol. 135). John Benjamins Publishing.

Austin, J.L. (1962). How to do things with words. New York: Clardon Press.

Bijeikienė, V. \& Tamošiūnaitè, A. (2013). Quantitative and qualitative research methods in sociolinguistics: Study guide.

Bolden, G.B. (2016). A simple da?: Affirming responses to polar questions in Russian conversation. Journal of Pragmatics, 100, 40-58. doi: https://doi.org/10.1016/j.pragma.2015.07.010.

Channon, A., Foulkes, P., \& Walker, T. (2018). But what is the reason why you know such things?: Question and response patterns in the LADO interview. Journal of Pragmatics, $129,154-172$.

Englert, C. (2010). Questions and responses in Dutch conversations. Journal of Pragmatics, 42(10), 2666-2684. https://doi.org/doi: 10.1016/j.pragma.2010.04.005

He, H. (2013). Coding interviews: Questions, analysis \& solutions. Apress.

Holmes, J. (2001). An introduction to sociolinguistics. Pearson Education Limited

Hoey, E.M., \& Kendrick, K.H. (2017). Conversation analysis. Research Methods in Psycholinguistics: A Practical Guide, 151-173.

Jiang, F. (2013). Discourse analysis of job interview conversation: What and how to proceed in interaction. English for Specific Purposes World, 14.

Kärkkäinen, E. \& Thompson, S. A. (2018). Language and bodily resources:'Response packages' in response to polar questions in English. Journal of Pragmatics, 123, 220-238. https://doi.org/doi.org/10.1016/j.pragma.2017.05.003

Lee, S.H. (2016). Information and affiliation: Disconfirming responses to polar questions and what follows in third position. Journal of Pragmatics, 100, 59-72. doi: https://doi.org/10.1016/j.pragma.2015.10.003

Levinson, S.C. (1983). Pragmatics. Cambridge: Cambridge University Press.

Liddicoat, A.J. (2011). An introduction to conversation analysis. Bloomsbury Publishing. 
Markee, Numa. (2000). Conversation analysis. London, New Jersey: Lawrence Erlbaum Associates Publishers.

Rahardi, K. (2009). Sosiopragmatik. Jakarta: Erlangga.

Raymond, C. W. (2015). Questions and responses in Spanish monolingual and Spanish-English bilingual conversation. Language \& Communication, 42, 50-68. doi: https://doi.org/http://dx.doi.org/10.1016/j.iangcom.2015.02.001

Schleef, E. \& Meyerhoff, M. (2010). Sociolinguistic methods for data collection and interpretation. In The Routledge sociolinguistics reader. Schleef, Erik and Meyerhoff, Miriam (Eds.) (pp.1-17). London: Routledge.

Sidnell, J. \& Stivers, T. (Eds.). (2013). The handbook of conversation analysis. Oxford: WileyBlackwell.

Stivers, T. (2010). An overview of the question-response system in American English conversation. Journal of Pragmatics, 42(10), 2772-2781 doi: 10.1016/j.pragma.2010.04.011

Stivers, T. \& Sidnell, J. (Eds.). (2013). The handbook of conversation analysis. Oxford: WileyBlackwell.

Stivers, T., Sidnell, J., \& Bergen, C. (2018). Children's responses to questions in peer interaction: A window into the ontogenesis of interactional competence. Journal of Pragmatics, 124, 14-30. doi: https://doi.org/10.1016/j.pragma.2017.11.013

Ten Have, P. (2004). Understanding qualitative research and ethnomethodology. Sage.

Yule, G. (1996). Pragmatics. New York: Oxford University Press. 